\title{
Effects of Extracorporeal Shockwave Therapy and Hand Massage on Body Composition and Serum Lipids According to Serum Cholesterol Level in Korean Women
}

\author{
Kyung Jin Lee', ${ }^{1,2}$, Jin Ik Park' ${ }^{1}$, Soo Yeon $\mathrm{Oh}^{2}$ \\ ${ }^{1}$ Yangsan Kangnam Clinic, Yangsan, Republic of Korea \\ ${ }^{2}$ Department of Beauty Art, Graduate School of Youngsan University, Busan, Republic of Korea \\ Email: dangjin8676@naver.com
}

How to cite this paper: Lee, K.J., Park, J.I. and Oh, S.Y. (2019) Effects of Extracorporeal Shockwave Therapy and Hand Massage on Body Composition and Serum Lipids According to Serum Cholesterol Level in Korean Women. Journal of Cosmetics, Dermatological Sciences and Applications, 9, 177-187.

https://doi.org/10.4236/jcdsa.2019.92015

Received: April 19, 2019

Accepted: June 2, 2019

Published: June 5, 2019

Copyright $\odot 2019$ by author(s) and Scientific Research Publishing Inc. This work is licensed under the Creative Commons Attribution International License (CC BY 4.0).

http://creativecommons.org/licenses/by/4.0/

\begin{abstract}
Obesity, particularly abdominal obesity, increases the risk of cardiovascular disease (CVD). This study investigates the effects of six-week (twice a week, 12 sessions total) extracorporeal shockwave therapy (SWT) and hand massage therapy (HT) on body composition and serum lipids in overweight and obese Korean women aged between 35 and 59, according to their serum cholesterol level $(\geq 200 \mathrm{mg} / \mathrm{dL}$ versus $<200 \mathrm{mg} / \mathrm{dL})$. After the program, weights decreased significantly in both the HT Group and SWT Group ( $<<0.05)$; weights of those with cholesterol $<200 \mathrm{mg} / \mathrm{dL}$ significantly decreased in the HT Group ( $\mathrm{p}=0.038$ ), while weights of those with cholesterol $\geq 200 \mathrm{mg} / \mathrm{dL}$ significantly decreased in the SWT Group $(\mathrm{p}=0.001)$. BMIs decreased significantly in both the HT Group and the SWT Group (p < 0.05); BMIs of those with cholesterol $<200 \mathrm{mg} / \mathrm{dL}$ significantly decreased in the HT Group ( $\mathrm{p}=$ 0.018), while BMIs of those with cholesterol $\geq 200 \mathrm{mg} / \mathrm{dL}$ significantly decreased in the SWT Group ( $\mathrm{p}=0.001)$. The body fat percentage of subjects significantly decreased only in the SWT Group $(\mathrm{p}=0.027)$; the waist-hip ratio significantly decreased only in HT Group $(p=0.034)$. Serum cholesterol levels significantly decreased in those with cholesterol $<200 \mathrm{mg} / \mathrm{dL}$ in the HT Group ( $<0.05$ ) and those with cholesterol $\geq 200 \mathrm{mg} / \mathrm{dL}$ in SWT Group (p = $0.055)$. Triglyceride significantly decreased in both those with cholesterol < $200 \mathrm{mg} / \mathrm{dL}$ and those with cholesterol $\geq 200 \mathrm{mg} / \mathrm{dL}$, but did not significantly decrease in either subgroup of the HT Group. The study results suggest that SWT is effective in improving body measurements and serum lipids in those with cholesterol $\geq 200 \mathrm{mg} / \mathrm{dL}$, while HT therapy is effective in those with cholesterol $<200 \mathrm{mg} / \mathrm{dL}$. In conclusion, SWT and HT improved abdominal obesity by reducing body weight and waist circumference and helped im-
\end{abstract}


proving serum lip index, suggesting the benefit for managing body measurements and serum lipids of overweight and obese individuals.

\section{Keywords}

Shockwave Therapy, Hand Massage, Body Composition, Cholesterol Level

\section{Introduction}

Around 17 million people around the world die from cardiovascular disease (CVD) each year, accounting for $30 \%$ of all deaths [1] [2]. The risk factors for CVD include lifestyle, such as smoking, hypertension, diabetes, dietary problems, lack of exercise, and overweight, and obesity, among which the latter is known to be important [3]. It has been found that abdominal obesity has been consistently increasing with the prevalence of overweight and obesity [4]; especially, abdominal fat deposition is a major risk factor for CVD [5] and is closely related to dyslipidemia [6]. Many studies with obese or overweight people have reported a decrease in total cholesterol, LDL cholesterol, and triglyceride levels in blood during weight loss [7], and management of abdominal obesity is particularly important in preventing CVD. Dyslipidemia, a CVD risk factor, is more common in middle-aged women than in men of the same age in Korea [8], and both management of abdominal obesity and improvement in serum lipids are crucial for preventing CVD. Abdominal obesity can be managed in various ways, including drug therapy, diet and exercise therapy, behavior modification therapy, surgery, device therapy, and massage therapy [9] [10]. Extracorporeal shockwave therapy uses physical force of shockwave to induce cavitation without damaging the skin or organ [11], and shockwave is known to be a noninvasive means to deliver therapeutically effective energy locally to a limited area, while reconstituting dermal collagen to improve cellulite skin [12]. On the other hand, hand massage strengthens muscles to improve blood flow to speed up healing, boosts long-term muscle recovery [13], and is an effective complementary therapy for patients suffering from elevated blood pressure due to stress [14]. Shockwave therapy and massage therapy are widely used for abdominal fat management in Korean medical centers, but no studies have examined their effects or resultant changes serum lipids.

This study investigates the effects of extracorporeal shockwave therapy and hand massage on body composition and serum lipids according to serum cholesterol level in overweight and obese Korean women.

\section{Methods}

\section{Study Participants and Period}

The inclusion criteria were as follows: body mass index of (BMI) $23 \mathrm{~kg} / \mathrm{m}^{2}$ or higher, waist-hip ratio (WHR) of 0.80 or higher, waist circumference of $80 \mathrm{~cm}$ or longer, without CVD (e.g., hypertension, hyperlipidemia, and diabetes), and no 
regular exercise for last six months (no moderate-to-high level of sweat-inducing physical activities for 30 minutes five days a week), and no obesity management (e.g., diet or medication for abdominal obesity) in last six months. Patients of our hospital were recruited, and 52 patients who gave informed consent were assigned to the extracorporeal shockwave therapy group and the hand massage therapy group in equal numbers. Two from the Shockwave Therapy Group and five from Hand Massage Group were excluded, as they wanted to withdraw from the study for personal reasons; a total of 43 patients participated in 12 sessions (twice a week for six weeks, 12 sessions total) (Figure 1).

Informed consent was obtained from each patient and the study protocol conforms to the ethical guidelines. The investigator signed the pledge to protect the hospital's patients and the pledge to protect privacy and confidentiality and obtained the final approval for participants' study participation based on their informed consents. The study was approved by Youngsan University Institutional Review Board (YSUIRB-201510-BR-003-02).

\section{Procedure}

\subsection{Extracorporeal Shockwave Therapy}

The shockwave therapy was conducted using a Joeun Medical ESWT (Model No. JESL-1000, Joeun Medical, Korea, 2013) with a unit head of $\varnothing 40 \mathrm{~mm}$, shock pressure of 5 bar, wave frequency of $10 \mathrm{~Hz}$, and 4000 shocks. It took 20 minutes to complete each therapy session, including preparation for the procedure (turning on the ESWT, sterilizing the head), applying cream to the abdomen to reduce surface friction for soft rubbing, pressing the footswitch to adjust the speed and gently rolling the head over the abdomen, and finishing with a heat pack.

\subsection{Hand Massage Therapy}

Hand massage therapy includes the following: Applying massage cream evenly on the bare abdomen followed by breathing, applying five manual techniques (stroking, rubbing, kneading, tapping, and shaking) followed by breathing, finishing with a hot pack. The procedure also took 20 minutes to complete.

\section{Instruments}

\subsection{Subjective Measure}

Participants were instructed to complete the questionnaire on general characteristics including age, child delivery, marital status, education level, occupation, and income, and the diet and exercise log (designed to show whether they maintain their usual diet and exercise prior to study participation to prevent the confounding effects of diet and exercise). Participants were fully informed of the study purpose, trained in how to fill out the questionnaire and the log, and instructed to maintain their usual diet and exercise for objective testing of the effects of the therapy in the investigation by controlling for extraneous variables. 


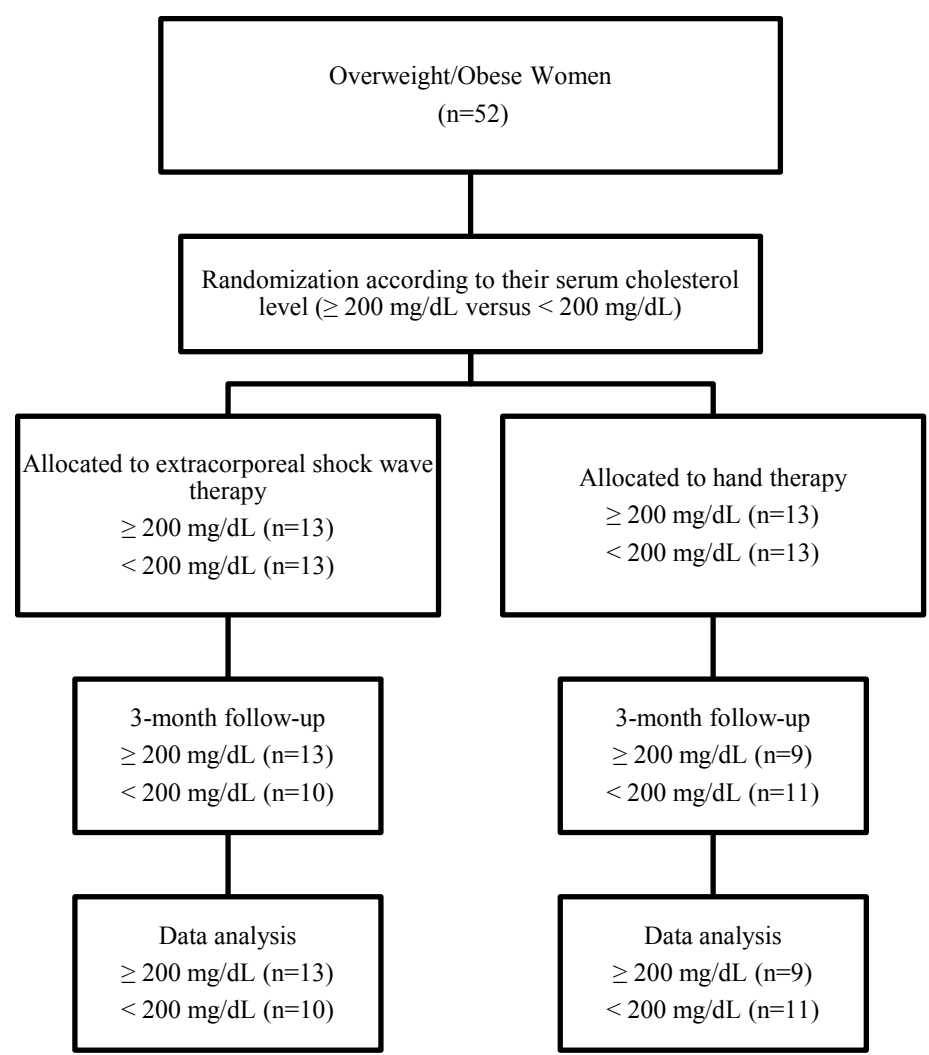

Figure 1. Study flow diagram.

\subsection{Physiological Measurement}

Measurement of body composition was conducted using a Genius 220 PLUS (Jawon Medical, Korea, 2010) and included weight $(\mathrm{kg})$, BMI $\left(\mathrm{kg} / \mathrm{m}^{2}\right)$, body fat percentage (\%), and waist-hip ratio (WHR). Waist circumference was measured around the midsection between the lowest point of the ribs and the highest point of the pelvis (iliac crest) using a Hoechstmass tape measure (made in Germany) while the participant was relaxed by exhaling with legs $25-30 \mathrm{~cm}$ apart; measurements were recorded in millimeters. Hematology was conducted by sampling the blood twice (before the first session and after the $12^{\text {th }}$ session) at $\mathrm{K}$ hospital at Yangsan after fasting for $12 \mathrm{~h}$. Hematology included measurements of TC, Triglyceride, HDL-C, and LDL-C using Hitachi 7600 - 110 (Japan, 2014), an automated biochemistry analyzer, and cortisol was measured using Roche COBAS8000 (Switzerland, 2014), an immunology analyzer.

\section{Data Analysis}

The data was analyzed using the Statistical Package for Social Science (SPSS) Win Version 23.0. The results are expressed as mean \pm standard deviation (SD). Prior to comparing the results between the Shockwave Therapy Group and Hand Massage Group, Shapiro-Wilk normality test was performed to test normality. The pretest-posttest difference was tested using the paired t-test, and the difference in post-treatment effects between the two groups was tested using the 
independent t-test.

\section{Results}

In this study, For the subjects, the mean age was $44.1 \pm 5.3$ years (range $36-49$ years). The mean height and weight of the subjects was $164.0 \mathrm{~cm}$ and $84.7 \mathrm{~kg}$, respectively. Body compositions changes in participants during the trial were presented in Table 1 . Body weight significantly decreased $(\mathrm{p}<0.05)$ in both the Hand Massage Group and Shockwave Therapy Group. In relation to serum cholesterol level, body weight significantly decreased in those with cholesterol $<200$ $\mathrm{mg} / \mathrm{dL}$ in the Hand Massage Group ( $\mathrm{p}=0.038$ ), and in those with cholesterol $\geq$ $200 \mathrm{mg} / \mathrm{dL}$ in the Shockwave Therapy Group ( $\mathrm{p}=0.001)$. However, after the 12 -week treatment period, there was no significant difference in body weight between the two groups $(\mathrm{p}=0.750)$. BMI significantly decreased after treatment in both groups ( $\mathrm{p}<0.05$ ); in relation to serum cholesterol level, BMI significantly decreased in those with cholesterol $<200 \mathrm{mg} / \mathrm{dL}$ in the Hand Massage Group $(\mathrm{p}=0.018)$, and in those with cholesterol $\geq 200 \mathrm{mg} / \mathrm{dL}$ in the Shockwave Therapy Group ( $p=0.001$ ). Body fat percentage significantly decreased only in the Shockwave Therapy Group ( $\mathrm{p}=0.027$ ), while WHR significantly decreased only in Hand Massage Group ( $\mathrm{p}=0.034)$. Regardless of cholesterol level, waist circumference significantly decreased in both groups $(\mathrm{p}<0.001)$, with a $10 \%$ decrease in Hand Massage Group and 8.8\% decrease in Shockwave Therapy Group. There was no significant difference in body weight, BMI, body fat percentage, waist-hip ratio, and circumference between the Shockwave Therapy Group and Hand Massage Group after the 6-week treatment.

Blood lipids changes in participants during the trial were presented in Table 2. In this study, serum cholesterol significantly decreased in those with cholesterol $<200 \mathrm{mg} / \mathrm{dL}$ in the Hand Massage Group $(\mathrm{p}<0.05)$, and in those with cholesterol $\geq 200 \mathrm{mg} / \mathrm{dL}$ in the Shockwave Therapy Group ( $\mathrm{p}=0.055)$. Triglycerides significantly decreased in the Shockwave Therapy Group ( $p<0.05$ ), but not in the Hand Massage Group. HDL-C and cortisol did not significantly decrease in either Shockwave Therapy Group and Hand Massage Group; LDL-C tended to decrease in those with cholesterol $\geq 200 \mathrm{mg} / \mathrm{dL}$ in the Hand Massage Group ( $p=0.082$ ). The post-treatment difference between the two experimental groups measured in 12 sessions in six weeks was significant for triglycerides and HDL $(\mathrm{p}<0.05)$ and insignificant for cholesterol, LDL, and cortisol.

\section{Discussion}

This clinical trial compared the effects of 6-week abdominal management with extracorporeal shockwave therapy and hand massage therapy in improving body composition and serum lipids in overweight and obese women according to serum cholesterol level.

According to the results, extracorporeal shockwave therapy and hand massage therapy each significantly reduced body weight, BMI, and weight circumference. 
Table 1. Body compositions changes in participants during the trial.

\begin{tabular}{|c|c|c|c|c|c|c|c|}
\hline & & \multicolumn{3}{|c|}{ Baseline } & \multicolumn{3}{|c|}{12 weeks } \\
\hline \multirow{6}{*}{$\begin{array}{c}\text { Body } \\
\text { weight }\end{array}$} & $\mathrm{HT}(\mathrm{n}=20)$ & 70.16 & \pm & 9.77 & 69.14 & \pm & $8.81^{\star}$ \\
\hline & $\operatorname{SWT}(\mathrm{n}=23)$ & 71.06 & \pm & 8.95 & 69.99 & \pm & $8.57^{\star *}$ \\
\hline & Cholesterol $<200 \mathrm{mg} / \mathrm{dL}+\mathrm{HT}(\mathrm{n}=11)$ & 68.11 & \pm & 7.41 & 66.95 & \pm & $5.96^{*}$ \\
\hline & Cholesterol $<200 \mathrm{mg} / \mathrm{dL}+\mathrm{SWT}(\mathrm{n}=10)$ & 67.42 & \pm & 7.39 & 67.02 & \pm & 7.21 \\
\hline & Cholesterol $\geq 200 \mathrm{mg} / \mathrm{dL}+\mathrm{HT}(\mathrm{n}=9)$ & 72.66 & \pm & 12.06 & 71.82 & \pm & 11.19 \\
\hline & Cholesterol $\geq 200 \mathrm{mg} / \mathrm{dL}+\mathrm{SWT}(\mathrm{n}=13)$ & 73.86 & \pm & 9.30 & 72.28 & \pm & $9.09^{* *}$ \\
\hline \multirow{6}{*}{ BMI } & $\mathrm{HT}(\mathrm{n}=20)$ & 26.58 & \pm & 3.13 & 26.20 & \pm & $2.88^{\star}$ \\
\hline & $\operatorname{SWT}(\mathrm{n}=23)$ & 26.81 & \pm & 2.92 & 26.36 & \pm & $2.72^{\star *}$ \\
\hline & Cholesterol $<200 \mathrm{mg} / \mathrm{dL}+\mathrm{HT}(\mathrm{n}=11)$ & 25.78 & \pm & 2.25 & 25.29 & \pm & $1.74^{\star}$ \\
\hline & Cholesterol $<200 \mathrm{mg} / \mathrm{dL}+\operatorname{SWT}(\mathrm{n}=10)$ & 25.49 & \pm & 1.70 & 25.32 & \pm & 1.67 \\
\hline & Cholesterol $\geq 200 \mathrm{mg} / \mathrm{dL}+\mathrm{HT}(\mathrm{n}=9)$ & 27.56 & \pm & 3.88 & 27.31 & \pm & 3.66 \\
\hline & Cholesterol $\geq 200 \mathrm{mg} / \mathrm{dL}+\mathrm{SWT}(\mathrm{n}=13)$ & 27.83 & \pm & 3.30 & 27.16 & \pm & $3.15^{\star *}$ \\
\hline \multirow{6}{*}{$\begin{array}{l}\text { Perent } \\
\text { of } \\
\text { body fat }\end{array}$} & $\mathrm{HT}(\mathrm{n}=20)$ & 34.17 & \pm & 3.69 & 33.74 & \pm & 4.05 \\
\hline & $\operatorname{SWT}(\mathrm{n}=23)$ & 34.69 & \pm & 3.37 & 34.20 & \pm & 3.00 \\
\hline & Cholesterol $<200 \mathrm{mg} / \mathrm{dL}+\mathrm{HT}(\mathrm{n}=11)$ & 33.69 & \pm & 2.71 & 33.25 & \pm & 2.51 \\
\hline & Cholesterol $<200 \mathrm{mg} / \mathrm{dL}+\mathrm{SWT}(\mathrm{n}=10)$ & 33.94 & \pm & 2.29 & 33.35 & \pm & 2.20 \\
\hline & Cholesterol $\geq 200 \mathrm{mg} / \mathrm{dL}+\mathrm{HT}(\mathrm{n}=9)$ & 34.76 & \pm & 4.73 & 34.32 & \pm & 5.52 \\
\hline & Cholesterol $\geq 200 \mathrm{mg} / \mathrm{dL}+\mathrm{SWT}(\mathrm{n}=13)$ & 35.26 & \pm & 4.00 & 34.85 & \pm & 3.43 \\
\hline \multirow{6}{*}{ Waist } & $\mathrm{HT}(\mathrm{n}=20)$ & 93.43 & \pm & 7.32 & 84.13 & \pm & $8.23^{* * *}$ \\
\hline & $\operatorname{SWT}(\mathrm{n}=23)$ & 93.77 & \pm & 5.67 & 85.47 & \pm & $5.40^{* * *}$ \\
\hline & Cholesterol $<200 \mathrm{mg} / \mathrm{dL}+\mathrm{HT}(\mathrm{n}=11)$ & 92.82 & \pm & 5.44 & 82.33 & \pm & $4.48^{* * *}$ \\
\hline & Cholesterol $<200 \mathrm{mg} / \mathrm{dL}+\mathrm{SWT}(\mathrm{n}=10)$ & 93.30 & \pm & 4.83 & 85.77 & \pm & $4.50^{* * *}$ \\
\hline & Cholesterol $\geq 200 \mathrm{mg} / \mathrm{dL}+\mathrm{HT}(\mathrm{n}=9)$ & 94.17 & \pm & 9.44 & 86.33 & \pm & $11.22^{* * *}$ \\
\hline & Cholesterol $\geq 200 \mathrm{mg} / \mathrm{dL}+\operatorname{SWT}(\mathrm{n}=13)$ & 94.14 & \pm & 6.41 & 85.24 & \pm & $6.18^{* * *}$ \\
\hline \multirow{6}{*}{$\begin{array}{c}\text { Abdominal } \\
\text { obesity }\end{array}$} & $\mathrm{HT}(\mathrm{n}=20)$ & 0.86 & \pm & 0.04 & 0.84 & \pm & $0.05^{*}$ \\
\hline & SWT $(n=23)$ & 0.85 & \pm & 0.04 & 0.85 & \pm & 0.03 \\
\hline & Cholesterol $<200 \mathrm{mg} / \mathrm{dL}+\mathrm{HT}(\mathrm{n}=11)$ & 0.85 & \pm & 0.02 & 0.84 & \pm & $0.03^{*}$ \\
\hline & Cholesterol $<200 \mathrm{mg} / \mathrm{dL}+\mathrm{SWT}(\mathrm{n}=10)$ & 0.84 & \pm & 0.02 & 0.84 & \pm & 0.02 \\
\hline & Cholesterol $\geq 200 \mathrm{mg} / \mathrm{dL}+\mathrm{HT}(\mathrm{n}=9)$ & 0.86 & \pm & 0.05 & 0.85 & \pm & 0.06 \\
\hline & Cholesterol $\geq 200 \mathrm{mg} / \mathrm{dL}+\mathrm{SWT}(\mathrm{n}=13)$ & 0.86 & \pm & 0.04 & 0.86 & \pm & 0.03 \\
\hline
\end{tabular}

HT; hand massage therapy group, SWT; Shockwave therapy group, ${ }^{*} \mathrm{p}<0.05,{ }^{* *} \mathrm{p}<0.01,{ }^{* * *} \mathrm{p}<0.001$ paired t-test (compared with baseline). 
Table 2. Body blood lipids changes in participants during the trial.

\begin{tabular}{|c|c|c|c|c|c|c|c|}
\hline & & \multicolumn{3}{|c|}{ Baseline } & \multicolumn{3}{|c|}{12 weeks } \\
\hline \multirow{6}{*}{$\begin{array}{c}\text { Total } \\
\text { cholesterol }\end{array}$} & $\mathrm{HT}(\mathrm{n}=20)$ & 196.65 & \pm & 37.10 & 196.00 & \pm & 33.76 \\
\hline & SWT $(\mathrm{n}=23)$ & 209.96 & \pm & 32.31 & 203.22 & \pm & 32.82 \\
\hline & Cholesterol $<200 \mathrm{mg} / \mathrm{dL}+\mathrm{HT}(\mathrm{n}=11)$ & 170.91 & \pm & 24.89 & 182.64 & \pm & 27.77 \\
\hline & Cholesterol $<200 \mathrm{mg} / \mathrm{dL}+\mathrm{SWT}(\mathrm{n}=10)$ & 181.90 & \pm & 12.35 & 177.30 & \pm & $24.66^{*}$ \\
\hline & Cholesterol $\geq 200 \mathrm{mg} / \mathrm{dL}+\mathrm{HT}(\mathrm{n}=9)$ & 228.11 & \pm & 21.67 & 212.33 & \pm & 34.61 \\
\hline & Cholesterol $\geq 200 \mathrm{mg} / \mathrm{dL}+\mathrm{SWT}(\mathrm{n}=13)$ & 231.54 & \pm & 25.27 & 223.15 & \pm & 23.00 \\
\hline \multirow{6}{*}{ Triglyceride } & $\mathrm{HT}(\mathrm{n}=20)$ & 117.60 & \pm & 64.53 & 115.95 & \pm & 62.60 \\
\hline & $\operatorname{SWT}(\mathrm{n}=23)$ & 108.65 & \pm & 37.38 & 82.22 & \pm & $35.06^{* * *}$ \\
\hline & Cholesterol < $200 \mathrm{mg} / \mathrm{dL}+\mathrm{HT}(\mathrm{n}=11)$ & 101.36 & \pm & 40.03 & 103.09 & \pm & 50.89 \\
\hline & Cholesterol $<200 \mathrm{mg} / \mathrm{dL}+\mathrm{SWT}(\mathrm{n}=10)$ & 104.20 & \pm & 36.66 & 66.80 & \pm & $24.04^{* *}$ \\
\hline & Cholesterol $\geq 200 \mathrm{mg} / \mathrm{dL}+\mathrm{HT}(\mathrm{n}=9)$ & 137.44 & \pm & 84.15 & 131.67 & \pm & $74.59 \dagger$ \\
\hline & Cholesterol $\geq 200 \mathrm{mg} / \mathrm{dL}+\mathrm{SWT}(\mathrm{n}=13)$ & 112.08 & \pm & 39.05 & 94.08 & \pm & $38.34^{*}$ \\
\hline \multirow{6}{*}{$\begin{array}{c}\text { HDL } \\
\text {-cholesterol }\end{array}$} & $\mathrm{HT}(\mathrm{n}=20)$ & 44.30 & \pm & 8.97 & 43.15 & \pm & 7.46 \\
\hline & SWT $(n=23)$ & 50.43 & \pm & 10.08 & 49.83 & \pm & 9.92 \\
\hline & Cholesterol < $200 \mathrm{mg} / \mathrm{dL}+\mathrm{HT}(\mathrm{n}=11)$ & 42.00 & \pm & 8.25 & 43.91 & \pm & 9.33 \\
\hline & Cholesterol $<200 \mathrm{mg} / \mathrm{dL}+\mathrm{SWT}(\mathrm{n}=10)$ & 47.20 & \pm & 6.12 & 48.20 & \pm & 8.16 \\
\hline & Cholesterol $\geq 200 \mathrm{mg} / \mathrm{dL}+\mathrm{HT}(\mathrm{n}=9)$ & 47.11 & \pm & 9.48 & 42.22 & \pm & $4.66 \dagger$ \\
\hline & Cholesterol $\geq 200 \mathrm{mg} / \mathrm{dL}+\mathrm{SWT}(\mathrm{n}=13)$ & 52.92 & \pm & 11.94 & 51.08 & \pm & 11.24 \\
\hline \multirow{6}{*}{$\begin{array}{c}\text { LDL } \\
\text {-cholesterol }\end{array}$} & $\mathrm{HT}(\mathrm{n}=20)$ & 120.90 & \pm & 33.10 & 118.50 & \pm & 32.44 \\
\hline & $\operatorname{SWT}(\mathrm{n}=23)$ & 129.13 & \pm & 30.91 & 123.74 & \pm & 30.30 \\
\hline & Cholesterol $<200 \mathrm{mg} / \mathrm{dL}+\mathrm{HT}(\mathrm{n}=11)$ & 99.36 & \pm & 23.58 & 105.55 & \pm & 27.07 \\
\hline & Cholesterol $<200 \mathrm{mg} / \mathrm{dL}+\mathrm{SWT}(\mathrm{n}=10)$ & 105.90 & \pm & 17.29 & 103.00 & \pm & 22.99 \\
\hline & Cholesterol $\geq 200 \mathrm{mg} / \mathrm{dL}+\mathrm{HT}(\mathrm{n}=9)$ & 147.22 & \pm & 22.15 & 134.33 & \pm & 32.73 \\
\hline & Cholesterol $\geq 200 \mathrm{mg} / \mathrm{dL}+\mathrm{SWT}(\mathrm{n}=13)$ & 147.00 & \pm & 27.05 & 139.69 & \pm & 25.54 \\
\hline \multirow{6}{*}{ Cortisol } & $\mathrm{HT}(\mathrm{n}=20)$ & 9.33 & \pm & 3.08 & 8.94 & \pm & 3.03 \\
\hline & SWT $(n=23)$ & 8.63 & \pm & 3.35 & 9.16 & \pm & 3.23 \\
\hline & Cholesterol $<200 \mathrm{mg} / \mathrm{dL}+\mathrm{HT}(\mathrm{n}=11)$ & 9.48 & \pm & 2.97 & 8.79 & \pm & 2.94 \\
\hline & Cholesterol $<200 \mathrm{mg} / \mathrm{dL}+\mathrm{SWT}(\mathrm{n}=10)$ & 8.89 & \pm & 3.23 & 9.86 & \pm & 3.38 \\
\hline & Cholesterol $\geq 200 \mathrm{mg} / \mathrm{dL}+\mathrm{HT}(\mathrm{n}=9)$ & 9.15 & \pm & 3.39 & 9.12 & \pm & 3.32 \\
\hline & Cholesterol $\geq 200 \mathrm{mg} / \mathrm{dL}+\mathrm{SWT}(\mathrm{n}=13)$ & 8.42 & \pm & 3.55 & 8.62 & \pm & 3.13 \\
\hline
\end{tabular}

HT: hand massage therapy group, SWT: Shockwave therapy group, ${ }^{*} \mathrm{p}<0.05,{ }^{* *} \mathrm{p}<0.01,{ }^{* * *} \mathrm{p}<0.001$ paired t-test (compared with baseline), $\dagger \mathrm{p}<0.05$ compared with Cholesterol $\geq 200 \mathrm{mg} / \mathrm{dL}+\mathrm{SWT}$ group. 
In addition, extracorporeal shockwave therapy significantly reduced body fat percentage, and hand massage therapy significantly reduced WHR. A previous study on combined manual acupuncture and massage therapy (MAMT) reported a significant reduction in body weight [15], and the body weight reduction in overweight and obese women demonstrated both in that study and the present study has large implications for improving dyslipidemia to reduce risks for CVD [2]. Elevated BMI due to abdominal or upper body obesity is associated with many diseases and metabolic abnormalities [16], and the present study found BMI reduction in obese patients subject to each treatment regime. However, the findings of a significant reduction in body weight, BMI, and WHR in those with cholesterol $<200 \mathrm{mg} / \mathrm{dL}$ in the Hand Massage Group and a significant reduction in body weight and BMI in those with cholesterol $\geq 200 \mathrm{mg} / \mathrm{dL}$ in the Shockwave Therapy Group suggest that those with high serum lipid level benefit more from shockwave therapy than from massage therapy. Considering that waist circumference is the best indicator for the risk of dyslipidemia [17], our finding of decrease in waist circumference due to shockwave and hand massage has much significance. A study on manual abdominal management with Korean women reported significant reduction in body weight and body fat, but no significant reduction in WHR, after 15 manual abdominal management sessions [18]; our study also found significant reduction in body weight, BMI, and weight circumference in both groups, but significant reduction in WHR only in the Hand Massage Group. Unlike a study of non-invasive ultrasound for intensive care in 12 weekly sessions that found a decreased circumference and fat thickness in the abdomen, thigh, or flank [19], the present study found a significant reduction in body fat in the Shockwave Therapy Group, but not in the Hand Massage Group; therefore, their effects on WHR and body fat need to be studied further with a larger, more diverse sample and a longer study period.

A variety of diet programs have shown positive effects on serum lipid level, as shown in a study of an 8-week obesity management program with middle aged obese women in the exercise group, high-frequency management group, and combined management group that reported a significant reduction in TC in the exercise and the combined management groups, according to hematological results $(\mathrm{p}<0.05)$ [20]. Therefore, the findings on the change in serum lipids in our study have large implications. The present study also found significant reduction in cholesterol in those with cholesterol $<200 \mathrm{mg} / \mathrm{dL}$ in the Hand Massage Group and significant reduction in triglycerides in those with cholesterol $<$ as well as those with $\geq 200 \mathrm{mg} / \mathrm{dL}$ in the Shockwave Therapy Group. This is consistent with another study's report of the improved metabolic parameters and serum lipid levels after the combined ultrasound cavitation and electro-lipolysis [21]. A significant reduction in triglycerides after shockwave therapy in the present study is also consistent with the previous research finding that electroacupuncture therapy reduced LDL greater in the obese group than in the control group ( $<<0.05)$, which suggests that the application of electro-acupuncture therapy in women 
may increase serum beta-endorphin levels to reduce total serum cholesterol, triglyceride, and LDL cholesterol [22]. Therefore, the positive changes in serum lipids due to shockwave and manual therapy programs are extremely significant and need to be studied further. Similar to earlier research findings of no significant differences in triglycerides, HDL, and LDL in middle aged women after 10 sessions of muscle relaxation massage and high-frequency treatment for five weeks [23], our study found no significant differences in HDL, LDL, and cortisol, although there was a significant difference in triglycerides.

The Adult Treatment Panel III (ATP III) of the National Cholesterol Education Program required administration of statins and therapeutic lifestyle change (TLC) [24]. Notable results were found in LDL due to manual therapy in the risk group with cholesterol $\geq 200 \mathrm{mg} / \mathrm{dL}$ with no statins and TLC in the present study; this is a positive result and suggests the need for further research.

Shockwave therapy and hand massage therapy, which are commonly performed in Korea and other Asian countries, are efficacious management therapy to improve abdominal obesity through improvement in body measurements and serum lipids. However, few studies have investigated obesity management with shockwave therapy. Moreover, as the present results obtained with a small sample in six week programs are not sufficient to make definite conclusions, further research on this topic with a larger, more diverse sample including a wider range of ages is needed.

This study has a special merit as the first study that compared the effects of shockwave and hand massage therapies, widely used in Korean hospitals, on serum lipids. The study found that both therapies improve body measurements such as body weight; shockwave therapy is highly effective in improving body measurement and serum lipids in those with serum cholesterol $\geq 200 \mathrm{mg} / \mathrm{dL}$, while hand massage therapy is highly effective in those with cholesterol $<200$ $\mathrm{mg} / \mathrm{dL}$. In conclusion, evidence suggests that shockwave therapy and hand massage therapy improve body weight and abdominal obesity in overweight and obese individuals and lowers serum cholesterol and triglycerides, thereby reducing risk of CVD.

\section{Acknowledgements}

This work was supported by a 2019 research grant from Youngsan University, Republic of Korea.

\section{Conflicts of Interest}

The authors declare no conflicts of interest regarding the publication of this paper.

\section{References}

[1] WHO (2015) Global Health Observatory (GHO) Data. https://www.who.int/gho/en/ 
[2] Howard, B.V., Ruotolo, G. and Robbins, D.C. (2003) Obesity and Dyslipidemia. Endocrinology \& Metabolism Clinics of North America, 32, 855-867. https://doi.org/10.1016/S0889-8529(03)00073-2

[3] Yusuf, S., Hawken, S., Ounpuu, S., Dans, T., Avezum, A., Lanas, F., et al. (2004) Effect of Potentially Modifiable Risk Factors Associated with Myocardial Infarction in 52 Countries (the Interheart Study): Case-Control Study. The Lancet, 364, 937-952. https://doi.org/10.1016/S0140-6736(04)17018-9

[4] Ford, E.S., Mokdad, A.H. and Giles, W.H. (2003) Trends in Waist Circumference among US Adults. Obesity Research, 11, 1223-1231. https://doi.org/10.1038/oby.2003.168

[5] Sharma, A.M. (2002) Adipose Tissue: A Mediator of Cardiovascular Risk. International Journal of Obesity and Related Metabolic Disorders, 26, S5-S7.

https://doi.org/10.1038/sj.ijo.0802210

[6] Després, J.-P., Arsenault, B.J., Côté, M., Cartier, A. and Lemieux, I. (2008) Abdominalobesity: The Cholesterol of the 21st Century? The Canadian Journal of Cardiology, 24, 7D. https://doi.org/10.1016/S0828-282X(08)71043-2

[7] Poobalan, A., Aucott, L., Smith, W.C., Avenell, A., Jung, R., Broom, J., et al. (2004) Effects of Weight Loss in Overweight/Obese Individuals and Long-Term Lipid Outcomes-A Systematic Review. Obesity Reviews, 5, 43-50. https://doi.org/10.1111/j.1467-789X.2004.00127.x

[8] Choi, E.J., Jekal, Y., Kim, S., Yoo, J.S., Kim, H.S., Oh, E.-G., et al. (2010) Middle-Aged Women's Awareness of Cholesterol as a Risk Factor: Results from a National Survey of Korean Middle-Aged Women's Health Awareness (KomWHA) Study. International Journal of Nursing Studies, 47, 452-460. https://doi.org/10.1016/j.ijnurstu.2009.09.002

[9] Lee, J.W., Yoo, S.Y., Yang, S.Y., Kim, H. and Cho, S.K. (2012) Effect of an Abdominal Obesity Management Program on Dietary Intake, Stress Index, and Waist to Hip Ratio in Abdominally Obese Women-Focus on Comparison of the WHR Decrease and WHR Increase Groups. Korean Journal of Nutrition, 45, 127-139. https://doi.org/10.4163/kjn.2012.45.2.127

[10] Kim, M.S. and Ahn, H.S. (2003) Study on the Effect of Obesity Management Program in Middle Aged Abdominal Obese Women-With Focus on Aroma Massage. Journal of Korean Society for the Study of Obesity, 12, 54-67.

[11] Wolfrum, B., Ohl, C.-D., Mettin, R., Kurz, T. and Lauterborn, W. (2003) Die Bedeutung von Kavitationsblasen fur transiente Membranpermeabilisierung und Zellschadigung. Fortschritte der Akustik, 29, 826-827.

[12] Angehrn, F., Kuhn, C. and Voss, A. (2007) Can Cellulite Be Treated with Low-Energy Extracorporeal Shock Wave Therapy? Clinical Interventions in Aging, 2, 623. https://doi.org/10.2147/CIA.S1721

[13] Vickers, A., Ohlsson, A., Lacy, J. and Horsley, A. (2004) Massage for Promoting Growth and Development of Preterm and/or Low Birth-Weight Infants. Cochrane Database of Systematic Reviews, No. 2, CD000390. https://doi.org/10.1002/14651858.CD000390.pub2

[14] Aourell, M., Skoog, M. and Carleson, J. (2005) Effects of Swedish Massage on Blood Pressure. Complementary Therapies in Clinical Practice, 11, 242-246. https://doi.org/10.1016/j.ctcp.2005.02.008

[15] He, J., Zhang, X., Qu, Y., Huang, H., Liu, X., Du, J., et al. (2015) Effect of Combined Manual Acupuncture and Massage on Body Weight and Body Mass Index Reduction in Obese and Overweight Women: A Randomized, Short-Term Clinical Trial. 
Journal of Acupuncture \& Meridian Studies, 8, 61-65. https://doi.org/10.1016/j.jams.2014.08.001

[16] Pi-Sunyer, F.X. (2002) The Obesity Epidemic: Pathophysiology and Consequences of Obesity. Obesity Research, 10, 97S-104S. https://doi.org/10.1038/oby.2002.202

[17] Lee, C.M.Y., Huxley, R.R., Wildman, R.P. and Woodward, M. (2008) Indices of Abdominal Obesity Are Better Discriminators of Cardiovascular Risk Factors than BMI: A Meta-Analysis. Journal of Clinical Epidemiology, 61, 646-653. https://doi.org/10.1016/j.jclinepi.2007.08.012

[18] Choi, S.-K., Lee, J.-S. and Song, J.-H. (2011) A Study on the Effect of Manual Therapy on the Body Composition, Stress Hormones, Visceral Fat of Obese Women. Asian Journal of Beauty and Cosmetology, 9, 1-16.

[19] Teitelbaum, S.A., Burns, J.L., Kubota, J., Matsuda, H., Otto, M.J., Shirakabe, Y., et al. (2007) Noninvasive Body Contouring by Focused Ultrasound: Safety and Efficacy of the Contour I Device in a Multicenter, Controlled, Clinical Study. Plastic and Reconstructive Surgery, 120, 779-789. https://doi.org/10.1097/01.prs.0000270840.98133.c8

[20] Jeon, H. (2013) Effect of Multi Obesity Treatment Program of Exercise, High Frequency Machine and Energy Restriction on Serum Lipids and Serum Hormone in Obese Women. The Journal of Korea Society for Wellness, 8, 347-360.

[21] Sabbour, A. and El-Banna, A. (2009) The Efficiency of Cavitation Ultrasound Therapy on Visceral Adiposity in Perimenpausal Women. Bulletin of Faculty of Physical Therapy, 14, 93-102.

[22] Tuğrul Cabıoğlu, M. and Ergene, N. (2005) Electroacupuncture Therapy for Weight Loss Reduces Serum Total Cholesterol, Triglycerides, and LDL Cholesterol Levels in Obese Women. The American Journal of Chinese Medicine, 33, 525-533. https://doi.org/10.1142/S0192415X05003132

[23] Jung, H.J. and Lim, M. (2013) Effect of Myofascial Massage and High Frequency Treatment on Middle Aged Women's Abdominal Obesity. Journal of the Korean Society of Cosmetology, 19, 596-606.

[24] Grundy, S.M., Cleeman, J.I., Merz, C.N.B., Brewer, H.B. and Clark, L.T., Hunninghake, D.B., et al. (2004) Implications of Recent Clinical Trials for the National Cholesterol Education Program Adult Treatment Panel III Guidelines. Journal of the American College of Cardiology, 44, 720-732. https://doi.org/10.1016/j.jacc.2004.07.001 